Iranica Journal of Energy \& Environment 2 (3): 235-243, 2011

ISSN 2079-2115

IJEE an Official Peer Reviewed Journal of Babol Noshirvani University of Technology

doi: 10.5829/idosi.ijee.2011.02.03.266

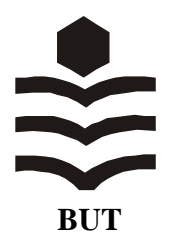

\title{
Phytotoxicity Assay of Crude Oil Using Different Accessions of Sorghum bicolor
}

\author{
K.L. Njoku M.O. Akinola and O.R. Oshodin \\ Department of Cell Biology and Genetics, \\ Environmental Biology Laboratory, University of Lagos, Akoka Lagos, Nigeria
}

(Received: January 21, 2011; Accepted: July 3, 2011)

\begin{abstract}
The toxicity of crude oil on ten accessions of Sorghum bicolor Moench was evaluated in this study. The study used germination, shoot length, root length, chromosomal abnormalities, mitotic indices and $\mathrm{EC}_{50}$ as bioassay parameters in the evaluation with $0 \%$ to $8 \%$ of crude oil as treatments. The percentage germination of seeds of the different accessions in the different treatments were significantly different $(p<0.05 ; p<0.01$ and $\mathrm{p}<0.001)$. Significant differences also existed in the rates at which the different accessions grew in the different treatment $(\mathrm{p}<0.05 ; \mathrm{p}<0.01$ and $\mathrm{p}<0.001)$. Chromosomal aberrations ranging from vagrant, bridged anaphase, c-metaphase amongst others were noticed in the cells of the seedlings exposed to the different treatments. The $\mathrm{EC}_{50}$ of the different accession ranged from 5.5\% to $19 \%$ for germination, $4.4 \%$ to $13.8 \%$ for root length and $6.3 \%$ to $16.7 \%$ for shoot length. The mitotic indices of the plants were also affected by the different treatments. The results of the study shows that although the different assay parameters show that crude oil can affect different plants in the different ways, $07 / 125$ is more sensitive to crude oil pollution. Further studies can be carried out on the more resistant accessions to determine their suitability for remediation of crude oil contaminated sites.
\end{abstract}

Key words: Phytotoxicity \%Assay \%Crude Oil \%Sorghum bicolor

\section{INTRODUCTION}

The impacts of crude oil and other petroleum products on the ecosystem and organisms have been reported by several authors [1-5]. Oil pollution in whatever form is toxic to plants and soil micro-organisms $[6,7]$. According to [8] due to the toxicity, widespread presence and complex nature of petroleum, pollution due to petroleum has become a serious problem. Petroleum hydrocarbons in soils adversely affect the germination and growth of plants in soils [9]. Oil spills affect plants adversely by creating conditions which make essential nutrients like nitrogen and oxygen needed for plant growth unavailable to them.

The impacts of chemicals on the environment can be detected through toxicity testing. Toxicity tests have been suggested as useful tools in assessing the risk of contaminated soil [10-13]. Furthermore, toxicity tests have been suggested as useful tools in assessing the risk of contaminated soil or to evaluate the efficacy of a remediation process.
There are many toxicity tests that can be used to determine acute and chronic effects of chemicals and for the monitoring and assessing the risk of new chemicals and xenobiotics or for the evaluation of the toxicity of environmental pollutants [14]. Such toxicity testing techniques include genotoxicity, phytotoxicity, while toxicity parameters include germination, root length, mean lethal dose $\left(\mathrm{LD}_{50}\right)$, median effective concentration $\left(\mathrm{EC}_{50}\right)$, etc.

Phytotoxicity assays involve the use of plants to determine toxicity of chemicals. It helps in selecting plant species that are able to withstand high levels of contaminants and screening out those that are not able to establish themselves in such conditions as present in contaminated sites [15]. According to Omosun et al. [16], the responses of plants to pollutants provide a simple and cost effective method of monitoring environmental pollutants. Plant bioassays such as measurements of seed germination and early seedling growth have been used to monitor treatment effects of oil-contaminated sites [17].

Corresponding Author: K.L. Njoku, Department of Cell Biology and Genetics, Environmental Biology Laboratory, University of Lagos, Akoka Lagos, Nigeria. E-mail: kecynjoku@gmail.com. 
This is because germination and root elongation are two critical stages in plant development that are sensitive to environmental contaminants [18]. Plant height and shoot biomass are also good indicators of plant health and the sustenance of plant growth by the treated substrates or soil is an indication of enhanced bioremediation [19].

Environmental pollutants and toxic substances are assessed with various organisms [20-23]. Because of their stationary nature, plants are most times preferred in toxicity as their nature eliminates the fear of improve identification of source and points of pollution mostly experienced with use of animals. Plant bioassays such as measurements of seed germination and early seedling growth have been used to monitor treatment effects and restoration of oil-contaminated sites [24, 17].

For plant effect monitoring, pollution induced changes in individual parameters of plants are quantified and correlated with the level of pollutants [16]. In this study, different accessions of Sorghum bicolor were used assess the toxicity of crude oil. It involved using different parameters like germination, root and shoot lengths, chromosomal aberrations and mitotic indices. The study is also important because the result obtained can help in the biological monitoring of soils to estimate the level of contamination. It is hoped that data obtained will help to guide both the agriculturalists on the accession that can be planted in soil with different levels of crude oil contamination and the environmentalists on the accession that can be tried for remediation of crude oil contaminated soils.

\section{MATERIALS AND EMTHODS}

The seeds of the accession of Sorghum bicolor used in this study were obtained from the gene bank of National Centre for Genetic Resources and Biotechnology (NACGRAB), Ibadan Nigeria. The accessions are 07/005, 07/012, 08/001, 07/143, 07/094, 07/018, 08/030, 07/151, $07 / 125$ and $07 / 182$. Viability tests were carried out on the seeds and ten seeds of each accession were planted in Petri-dishes lined with filter paper and wetted with the different concentrations of crude oil. The concentrations are $0.0,2,4,6$ and $8 \%$ obtained by mixing appropriate volumes of crude oil with distilled water (v/v). Each concentration served as a treatment and was replicated thrice.
The number of seeds that germinated from each treatment was recorded after three days and the percentage germination was calculated as was described by Njoku et al. [3]. The early seedling growth of the accessions in the different treatments were determined using the shoot length and the root length 10 days after the germination of the seeds as was described by Akinola and Njoku [3]. The mitotic indices and chromosomal aberrations were evaluated using the methods of Odiegah et al. [25] and Inceer et al. [26] while the EC50 was determined as was described by Akinola and Njoku [3]. Data obtained were statistically analysed with Graphpad prism 5.0 software using two way ANOVA followed by bonferroni posttests analysis.

\section{RESULTS}

Generally more seeds germinated from the $0 \%$ treatment than in the other treatments except the seeds of 07/005, 08/030 and 07/151 accessions. The germination of the seeds of 07/005 accession was generally more affected by all the treatments than the other accessions. The percentage germination of the seeds in the different treatments were significantly different from each other $(\mathrm{p}<0.001, \mathrm{p}<0.01$ and $\mathrm{p}<0.05)$. The percentage germination of seeds of 07/012, 07/125,07/094 and 07/018 were significantly lower in the $4 \%$ treatment than in the control $(p<0.05 ; p<0.01)$. In the $6 \%$ treatment, the percentage germination of the seeds of 07/012 and 07/143 were significantly lower than in the control treatment $(\mathrm{p}<0.01$; $\mathrm{p}<0.001$ ). the percentage germination of seeds of $07 / 012$, $07 / 143$ and $07 / 094$ in the $8 \%$ treatment were significantly lower than those in the control treatment at $99.9 \%$ level of significance while the percentage germination of the seeds of 07/125 and 08/001 accessions were significantly lower than those in the control treatment at $99 \%$ significance level.

The shoot lengths of the seedlings of the accessions of S. bicolor are shown in Figure 2. The shoot lengths of the plants did not totally follow a particular pattern although the shoot length. However, the $0 \%$ treatment led highest shoot length in most plants while with the exception of 07/012, 07/125 and 07/151 accessions, all the plants were shortest in the $8 \%$ treatment. The shoot lengths of the seedlings of the accessions in the different seedlings were significantly different from each other $(\mathrm{p}<0.05 ; \mathrm{p}<0.01$ and $\mathrm{p}<0.001)$. The shoots of the seedlings of $07 / 125$ and $07 / 151$ accessions were significantly shorter in the $4 \%$ treatment than in the control treatment $(\mathrm{p}<0.05)$ 


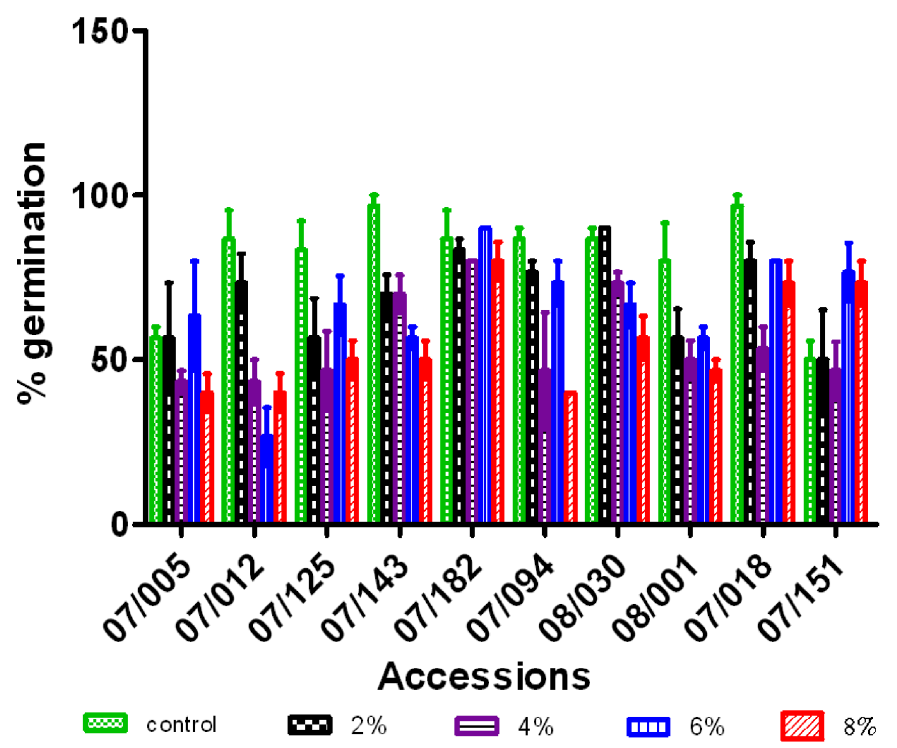

Fig. 1: The percentage germination of the different accessions of Sorghum bicolor treated with different concentrations of crude oil. Values are means \pm standard error of three replicates treatments

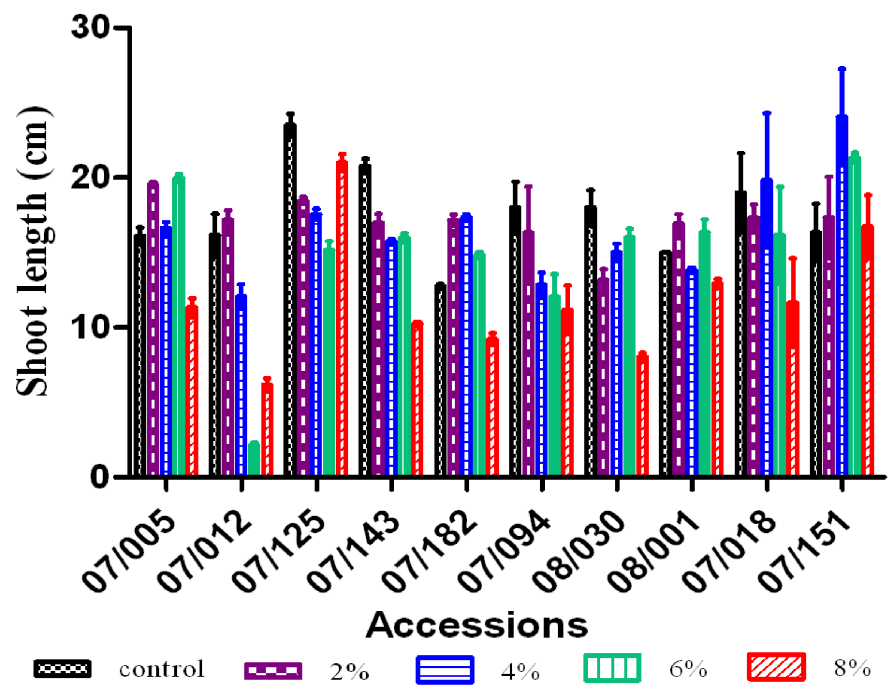

Fig. 2: The shoot length of the different accessions of Sorghum bicolor treated with different concentrations of crude oil. Values are means \pm standard error of three replicates treatments

and $(\mathrm{p}<0.01)$ respectively. Also the seedlings of $07 / 012$ and $07 / 125$ had shorter shoot length in the $6 \%$ treatment than in the control treatment at $\mathrm{p}<0.001$ and $\mathrm{p}<0.05$ respectively. At $\mathrm{p}<0.001$, the shoot lengths of $07 / 012$, $07 / 143$ and $08 / 030$ were significantly shorter in the $8 \%$ treatment than in the control treatment. The shoot length of the seedling of $07 / 018$ was significantly shorter in the $8 \%$ treatment than in the control treatment $(\mathrm{p}<0.01)$.

The roots of the seedlings of $07 / 012$ were generally shorter than the roots of other seedlings (Figure 3). However the root of the seedling of the accession treated with $8 \%$ crude oil was longer than the roots of the seedling of the accessions of 08/030, 07/143, 07/182 and $07 / 005$ treated with the same concentration of crude oil. Significant differences exist between the root lengths of the accessions treated with different levels of crude oil $(\mathrm{p}<0.05 ; \mathrm{p}<0.01 ; \mathrm{p}<0.001)$. The roots of the $07 / 143$ accession in the 2, 4, 6 and $8 \%$ treatments were significantly shorter than the roots of the accession in the control treatment $(\mathrm{p}<0.05 ; \mathrm{p}<0.01$ and $\mathrm{p}<0.001)$. The roots of the $07 / 151$ in the 4 and $6 \%$ treatments were also significantly shorter than the roots 


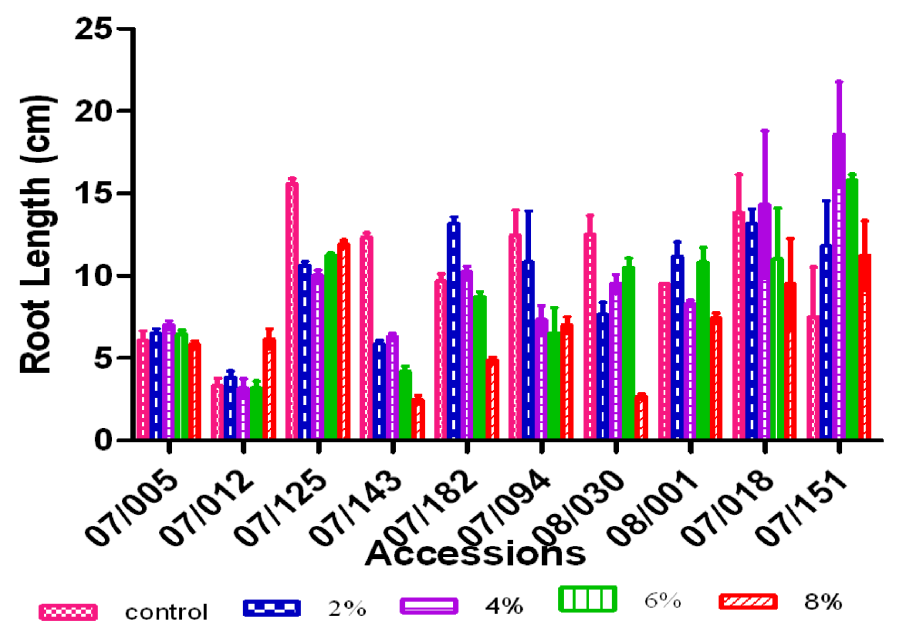

Fig. 3: The root length of the different accessions of Sorghum bicolor treated with different concentrations of crude oil. Values are means \pm standard error of three replicates treatments.

Table 1: The $\mathrm{EC}_{50}$ crude oil on the different accession of Sorghum bicolor using \% germination, root length and shoot length as the bioassay

\begin{tabular}{lccc}
\multicolumn{3}{c}{ parameters } & \\
\hline Accession & $\mathrm{EC}_{50}$ & $\mathrm{EC}_{50}$ & \multicolumn{1}{l}{$\mathrm{EC}_{50}$} \\
& Germination, \% & Root length, \% & Shoot length, \% \\
\hline $07 / 151$ & 11.2 & 10.9 & 12.10 \\
$07 / 018$ & 8.1 & 11.1 & 16.70 \\
$08 / 001$ & 9.2 & 12.3 & 10.80 \\
$08 / 030$ & 12.2 & 5.0 & 9.90 \\
$07 / 094$ & 7.2 & 6.2 & 9.10 \\
$07 / 182$ & 19.0 & 8.0 & 10.03 \\
$07 / 143$ & 7.1 & 4.4 & 8.00 \\
$07 / 125$ & 10.2 & 8.6 & 7.80 \\
$07 / 012$ & 5.5 & 13.8 & 6.30 \\
$07 / 005$ & 12.3 & 17.2 & 10.30 \\
\hline
\end{tabular}

of the plant in the control treatment $(\mathrm{p}<0.001)$. The roots of the seedlings of $07 / 094$ in the $6 \%$ treatment were also significantly shorter than those of the accession in the control treatment.

The effective concentrations that produced $50 \%$ effect $\left(\mathrm{EC}_{50}\right)$ on the different accession are shown in Table 1 . The 07/012 accession had the highest $\mathrm{EC}_{50}$ of $13.8 \%$ while $07 / 143$ accession had the lowest $\mathrm{EC}_{50}$ of $4.4 \%$ on the root length. The $\mathrm{EC}_{50}$ for the percentage germination ranged $5.5 \%$ in the $07 / 012$ accession to $19 \%$ in the $07 / 182$ accession. The $\mathrm{EC}_{50}$ for the shoot length was lowest $(6.3 \%)$ in the $07 / 012$ accession and highest $(16.7 \%)$ in the $07 / 018$ accession.

The effect of crude oil on the mitotic stages of the different plants is shown on Table 2. Apart from the prophase stage in the 07/151, 07/182 and 08/030 accessions, the control treatment allowed the cells of the plants to into the different stages of mitosis. Treatment of the plants with the different concentrations of crude oil led absence of one or more stages of mitosis with the $8 \%$ treatment leading to loss of more stages of mitosis.

The mitotic indices of the different accessions of $S$. bicolor exposed to different levels of crude oil are shown in Table 3. Although with slight deviations, the mitotic indices for the different accession decreased with the increase in the concentration of crude oil. Generally the 07/182 accession had the lowest mitotic indices in the different treatments with crude oil while the 08/001 accession had the highest mitotic indices. The $2 \%$ treatment produced the highest mitotic index in the $07 / 005$ accession while in the other accessions, the highest mitotic index was produced by the control $(0 \%)$ treatment.

The exposure of the crops to crude oil led the chromosomal aberrations. The $8 \%$ treatment led to more aberrations than the other treatments. There were vagrant chromosomes, laggard, bridged anaphase and c-metaphase as a result of $8 \%$ treatment while the $6 \%$ treatment led to the production bridged anaphase and vagrant chromosomes. The $4 \%$ treatment led to the production of multipolar cells and cells with bridged anaphase. Only vagrant chromosomes were produced by $2 \%$ treatment. Some of the aberrations due to the exposure of the plants to different concentrations of crude oil are shown in Plate 1. 
Iranica J. Energy \& Environ., 2 (3): 235-243, 2011

Table 2: The mitotic stages of the different accessions of S. bicolor treated with different concentrations of crude oil

\begin{tabular}{|c|c|c|c|c|c|c|c|}
\hline $\mathrm{S} / \mathrm{N}$ & Accession & Mitotic Stage & Control & $2 \%$ & $4 \%$ & $6 \%$ & $8 \%$ \\
\hline \multirow[t]{4}{*}{1} & $07 / 005$ & Prophase & $\%$ & $\%$ & $\%$ & - & $\%$ \\
\hline & & Metaphase & $\%$ & $\%$ & $\%$ & $\%$ & $\%$ \\
\hline & & Anaphase & $\%$ & $\%$ & $\%$ & $\%$ & - \\
\hline & & Telophase & $\%$ & $\%$ & $\%$ & $\%$ & - \\
\hline \multirow[t]{4}{*}{2} & $07 / 012$ & Prophase & $\%$ & $\%$ & - & $\%$ & $\%$ \\
\hline & & Metaphase & $\%$ & $\%$ & $\%$ & $\%$ & $\%$ \\
\hline & & Anaphase & $\%$ & $\%$ & $\%$ & - & $\%$ \\
\hline & & Telophase & $\%$ & - & $\%$ & $\%$ & - \\
\hline \multirow[t]{4}{*}{3} & $07 / 125$ & Prophase & $\%$ & $\%$ & $\%$ & $\%$ & $\%$ \\
\hline & & Metaphase & $\%$ & $\%$ & $\%$ & $\%$ & $\%$ \\
\hline & & Anaphase & $\%$ & - & - & $\%$ & $\%$ \\
\hline & & Telophase & $\%$ & $\%$ & $\%$ & - & $\%$ \\
\hline \multirow[t]{4}{*}{4} & $07 / 143$ & Prophase & $\%$ & $\%$ & $\%$ & - & $\%$ \\
\hline & & Metaphase & $\%$ & $\%$ & $\%$ & $\%$ & $\%$ \\
\hline & & Anaphase & $\%$ & $\%$ & $\%$ & $\%$ & $\%$ \\
\hline & & Telophase & $\%$ & $\%$ & $\%$ & - & - \\
\hline \multirow[t]{4}{*}{5} & $07 / 182$ & Prophase & - & - & - & $\%$ & $\%$ \\
\hline & & Metaphase & $\%$ & $\%$ & $\%$ & $\%$ & $\%$ \\
\hline & & Anaphase & $\%$ & $\%$ & $\%$ & $\%$ & $\%$ \\
\hline & & Telophase & $\%$ & $\%$ & & - & - \\
\hline \multirow[t]{4}{*}{6} & 07/094 & Prophase & $\%$ & $\%$ & $\%$ & - & - \\
\hline & & Metaphase & $\%$ & $\%$ & $\%$ & $\%$ & $\%$ \\
\hline & & Anaphase & $\%$ & $\%$ & $\%$ & $\%$ & $\%$ \\
\hline & & Telophase & $\%$ & $\%$ & $\%$ & $\%$ & - \\
\hline \multirow[t]{4}{*}{7} & $08 / 030$ & Prophase & - & - & $\%$ & $\%$ & - \\
\hline & & Metaphase & $\%$ & $\%$ & $\%$ & $\%$ & $\%$ \\
\hline & & Anaphase & $\%$ & $\%$ & $\%$ & - & $\%$ \\
\hline & & Telophase & $\%$ & $\%$ & - & $\%$ & $\%$ \\
\hline \multirow[t]{4}{*}{8} & 08/001 & Prophase & $\%$ & $\%$ & $\%$ & - & $\%$ \\
\hline & & Metaphase & $\%$ & $\%$ & $\%$ & $\%$ & $\%$ \\
\hline & & Anaphase & $\%$ & $\%$ & $\%$ & $\%$ & - \\
\hline & & Telophase & $\%$ & $\%$ & - & $\%$ & $\%$ \\
\hline \multirow[t]{4}{*}{9} & 07/018 & Prophase & $\%$ & $\%$ & - & $\%$ & $\%$ \\
\hline & & Metaphase & $\%$ & $\%$ & $\%$ & $\%$ & $\%$ \\
\hline & & Anaphase & $\%$ & $\%$ & $\%$ & $\%$ & - \\
\hline & & Telophase & $\%$ & $\%$ & $\%$ & - & $\%$ \\
\hline \multirow[t]{4}{*}{10} & $07 / 151$ & Prophase & - & - & - & - & - \\
\hline & & Metaphase & $\%$ & $\%$ & $\%$ & $\%$ & $\%$ \\
\hline & & Anaphase & $\%$ & $\%$ & $\%$ & - & $\%$ \\
\hline & & Telophase & $\%$ & $\%$ & $\%$ & $\%$ & - \\
\hline
\end{tabular}

Table 3: The mitotic indices of the accessions of Sorghum bicolor exposed to different concentrations of crude oil

\begin{tabular}{|c|c|c|c|c|c|c|c|}
\hline & Accession & & Control & $2 \%$ & $4 \%$ & $6 \%$ & $8 \%$ \\
\hline \multirow[t]{3}{*}{1} & $07 / 005$ & No. of counted cells & 1000.0 & 1000.0 & 1000.0 & 1000.0 & 1000.0 \\
\hline & & No. of dividing cells & 32.0 & 38.0 & 15.0 & 8.0 & 12.0 \\
\hline & & Mitotic index & 3.2 & 3.8 & 1.5 & 0.8 & 1.2 \\
\hline \multirow[t]{3}{*}{2} & 07/012 & No. of counted cells & 1000.0 & 1000.0 & 1000.0 & 1000.0 & 1000.0 \\
\hline & & No. of dividing cells & 25.0 & 14.0 & 12.0 & 18.0 & 10.0 \\
\hline & & Mitotic index & 2.5 & 1.4 & 1.2 & 1.8 & 1.0 \\
\hline \multirow[t]{3}{*}{3} & $07 / 125$ & No. of counted cells & 1000.0 & 1000.0 & 1000.0 & 1000.0 & 1000.0 \\
\hline & & No. of dividing cells & 21.0 & 16.0 & 12.0 & 13.0 & 18.0 \\
\hline & & Mitotic index & 2.1 & 1.6 & 1.2 & 1.3 & 1.8 \\
\hline \multirow[t]{3}{*}{4} & $07 / 143$ & No. of counted cells & 1000.0 & 1000.0 & 1000.0 & 1000.0 & 1000.0 \\
\hline & & No. of dividing cells & 23.0 & 14.0 & 13.0 & 10.0 & 9.0 \\
\hline & & Mitotic index & 2.3 & 1.4 & 1.3 & 1.0 & 0.9 \\
\hline \multirow[t]{3}{*}{5} & $07 / 182$ & No. of counted cells & 1000.0 & 1000.0 & 1000.0 & 1000.0 & 1000.0 \\
\hline & & No. of dividing cells & 20.0 & 11.0 & 8.0 & 6.0 & 4.0 \\
\hline & & Mitotic index & 2.0 & 1.1 & 0.8 & 0.6 & 0.4 \\
\hline
\end{tabular}


Table 3: Continued

\begin{tabular}{|c|c|c|c|c|c|c|c|}
\hline & Accession & & Control & $2 \%$ & $4 \%$ & $6 \%$ & $8 \%$ \\
\hline \multirow[t]{3}{*}{6} & $07 / 094$ & No. of counted cells & 1000.0 & 1000.0 & 1000.0 & 1000.0 & 1000.0 \\
\hline & & No. of dividing cells & 20.0 & 11.0 & 11.0 & 9.0 & 5.0 \\
\hline & & Mitotic index & 2.0 & 1.1 & 1.1 & 0.9 & 0.5 \\
\hline \multirow[t]{3}{*}{7} & 08/030 & No. of counted cells & 1000.0 & 1000.0 & 1000.0 & 1000.0 & 1000.0 \\
\hline & & No. of dividing cells & 21.0 & 13.0 & 10.0 & 8.0 & 6.0 \\
\hline & & Mitotic index & 2.1 & 1.3 & 1.0 & 0.8 & 0.6 \\
\hline \multirow[t]{3}{*}{8} & 08/001 & No. of counted cells & 1000.0 & 1000.0 & 1000.0 & 1000.0 & 1000.0 \\
\hline & & No. of dividing cells & 18.0 & 16.0 & 10.0 & 7.0 & 5.0 \\
\hline & & Mitotic index & 1.6 & 1.6 & 1.0 & 0.7 & 0.5 \\
\hline \multirow[t]{3}{*}{9} & 07/018 & No. of counted cells & 1000.0 & 1000.0 & 1000.0 & 1000.0 & 1000.0 \\
\hline & & No. of dividing cells & 27.0 & 19.0 & 15.0 & 13.0 & 10.0 \\
\hline & & Mitotic index & 2.7 & 1.9 & 1.5 & 1.3 & 1.0 \\
\hline \multirow[t]{3}{*}{10} & $07 / 151$ & No. of counted cells & 1000.0 & 1000.0 & 1000.0 & 1000.0 & 1000.0 \\
\hline & & No. of dividing cells & 17.0 & 12.0 & 9.0 & 6.0 & 3.0 \\
\hline & & Mitotic index & 1.7 & 1.2 & 0.9 & 0.6 & 0.3 \\
\hline
\end{tabular}

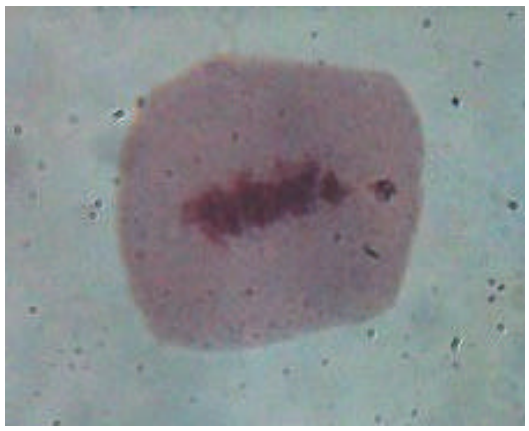

a)Laggard (8\% 07/125)

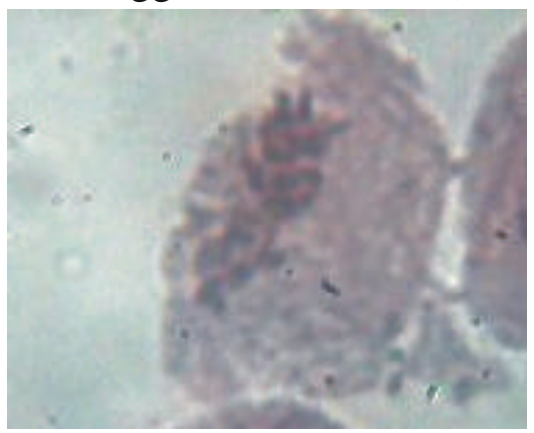

c) Vagrant (8\% 07/125)
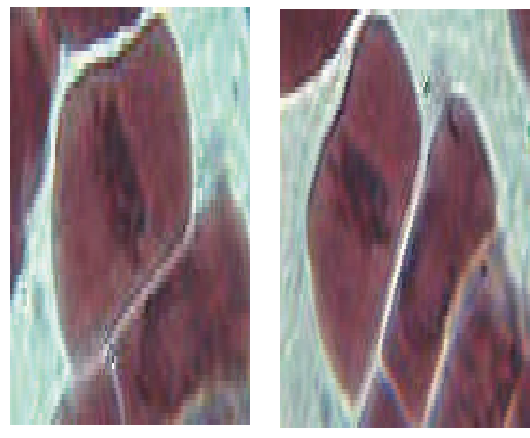

e) Bridged Anaphase (6\% 07/043)

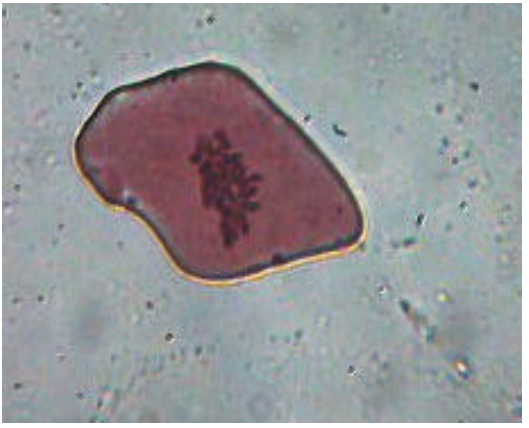

b) C-Metaphase (8\% 07/005)

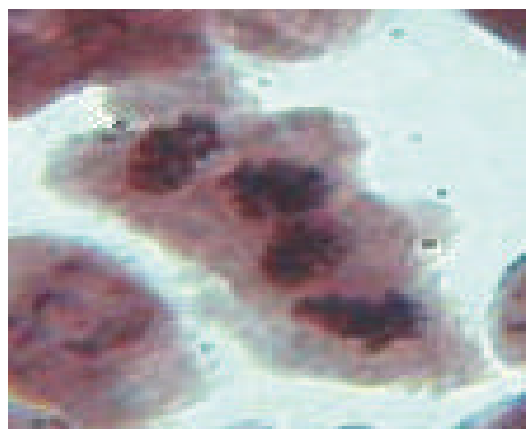

d) multipolar (4\% 07/005)

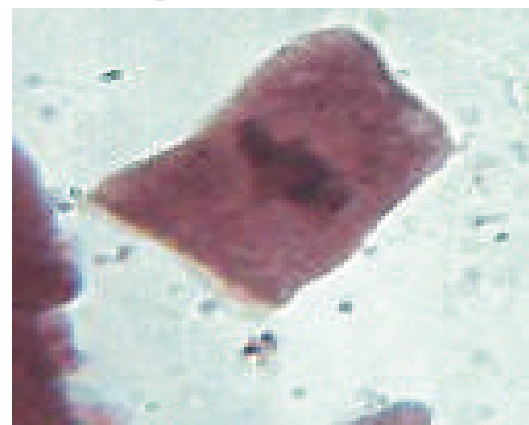

f) Bridged Anaphase (4\% 07/005)

Plate 1: Some chromosomal aberrations as a result of exposing different accessions of S. bicolor to different concentrations of crude oil 


\section{DISCUSSION}

The importance of using plants to study toxicity of chemicals has been stated by several authors. In this study the germination, growth and the chromosomes of the accessions of $S$. bicolor were inhibited by the different concentrations of crude oil. This is similar to what earlier studies have shown. For instance, Akinola and Njoku [3] reported decreased germination and growth of accessions of G. max in crude oil polluted media. According to Akinola and Njoku [3] the reduction of germination of the seeds of the accessions by the crude oil could be due to damaging of the germinating seeds by the oil or due to reduction of water imbibitions and gaseous exchange by the oil which can lead to death of the seeds.

From the studies, the different accessions of $S$. bicolor showed different sensitivity and resistance to crude oil pollution. This can be seen on the impact of crude oil on the germination, root length and shoot length developments of the plants. For instance it was noticed in this study that the seeds of $07 / 182$ accession generally had better germination than the seeds of other accessions while the seeds of $07 / 012$ were mostly affected by the crude oil than the seeds of the other accessions. Baek et al. [27] reported similar difference in sensitivity of corn and red bean exposed to crude oil. Also Akinola and Njoku [3] reported intraspecific differences in the sensitivity of different accessions of G. max to crude oil pollution. Using animals, O'Brein [28] also reported difference in the sensitivity of zooplankton (Branchionecta paladosa, D. middendofiana and Heterocope septentrionalis) to crude oil pollution. These could be due to the difference in the genetic make up of the plants [3] or due to differences in systemic uptake of oil compounds, nutrient availability and cell wall structural differences [29].

The median effective concentration $\left(\mathrm{EC}_{50}\right)$ shows the concentration of a chemical that inhibits performance in $50 \%$ of an organism. According to Akinola and Njoku (2007), the different $\mathrm{EC}_{50}$ values for the different accessions suggest that the different accessions of $S$. bicolor have different abilities to withstand crude oil pollution. Generally, the lower the $\mathrm{EC}_{50}$ value the higher the sensitivity of an organism to environmental condition. The evaluation of $\mathrm{EC}_{50}$ in this study shows that the germination and the shoot length development of 07/012 were more sensitive to crude oil than the germination and shoot length of the other accessions. The results of $\mathrm{EC}_{50}$ studies also show that the root length development of
07/143 accession is more sensitive to crude oil pollution than the root length development of the other accession. The inference from the $\mathrm{EC}_{50}$ studies is that the root length development of the 07/143 accession will be more inhibited by crude oil pollution than the root of the other accessions.

Since the growth of organisms more or less is a product of mitotic division, the results of the mitotic studies are significant in this study. The more or less low mitotic indices of the accessions show that crude oil pollution inhibit cell division in the accession and can also inhibit growth and development of the accessions. This means that crude oil is phytotoxic to $S$. color. From this it can be inferred that the growth of 07/182 accession will be inhibited more than the other accessions while the 08/001 accession will have the least impact on its growth when exposed to crude oil pollution.

The chromosomal aberrations noticed in this study indicate that exposure of plants to crude oil can lead to mutation or that crude oil apart from inhibiting plant growth can act as a clastogene. The altered chromosomes may possible have altered DNA and gene sequences which will affect the survival and continual existence of S. bicolor in crude oil polluted soil. The altered chromosomal structure especially vagrant and bridged chromosome due to crude oil which we observed in this study can also lead to improper arrangement of the chromosome strands during meiosis with subsequent effects like aneuploidy and cell death. The results of the chromosomal analyses show that higher concentrations of crude oil affect the chromosome and mitotic division of the accessions of $S$. bicolor more than the lower concentrations of crude oil. This similar to what earlier researchers have reported [25,3]. According to Akinola and Njoku [3], reduction of mitosis by crude oil can be the cause of the reduced growth of the plants in the crude oil polluted medium.

Generally, using the highest concentration (8\%) as a basis, the 07/012 accession showed to be the most sensitive accession of $S$. bicolor to crude oil pollution while the 07/125 accession showed to be the most resistant accession of $S$. bicolor to crude oil pollution. This means that while 07/012 accession will be good in biomonitoring of the environment for crude oil pollution, $07 / 125$ can be tried for its phytoremediation ability in cleaning up crude oil polluted soils. It is our suggestion that more studies to be carried out to evaluate the impact of crude on the DNA of the plants. These will help to give a clearer insight on the impact of crude oil on S. bicolor. 
There can also breeding studies on the accessions that had less damage on their chromosomes to produces that can adapt better to crude oil polluted media than the ones used in this work.

\section{REFERENCES}

1. Baker, J.M., 1970. The effects of oils on plants. Environmental Pollution, 1: 27-44.

2. Merkl, N., R. Schultze-Kraft and C. Infante, 2004. Phytoremediation in the tropics - The effect of crude oil on the growth of tropical plants. Bioremediation J., 8(3-4): 177-184.

3. Akinola, M.O. and K.L. Njoku 2007 Mutagenic effect of crude oil on the accessions of Glycine max L. (Merrill). Pakistan J. Science and Industrial Res., 50(5): 330-334.

4. Njoku K.L., M.O. Akinola and B.G. Taiwo, 2009a. Effect of gasoline diesel fuel mixture on the germination and the growth of Vigna unguiculata (Cowpea), African J. Environmental Sci. and Technol., 3(12): 466-471.

5. Njoku, K.L., M.O. Akinola and T.O. Ige, 2009b. Comparative Effects of Diesel Fuel and Spent Lubricating Oil on the Growth of Zea mays (Maize). American-Eurasian J. Sustainable Agric., 3(3): 428-434.

6. Adedokun, O.M. and A.E. Ataga, 2007. Effects of amendments and bioaugumentation of soil polluted with crude oil, automobile gasoline oil and spent engine oil on the growth of cowpea (Vigna unguiculata). Scientific Res. and Essay, 2(5): 147-149.

7. Adenipekun, C.O. and L.Q. Kassim, 2006. Effect of spent engine oil on some growth parameters and moisture content of Celosia argentea L. Nigeria J. Botany, 19(2): 318-324.

8. Wyszkowski, M., J. Wyszkowska and A. Zoilkowska, 2004. Effect of soil contaminated with diesel oil on yellow lupine yield and macroelements contents. Plant, Soil and Environment, 50(5): 218-226.

9. Hazel, W., 2005. Suck it up. Phytoremediation, organic Ade (online). http:// ourgardening. trpod.com/ organicAde.htm.

10. Chang L.W., J.R. Meier and M.K. Smith, 1997. Application of Plant and Earthworm bioassays to Evaluate Remediation of a Lead-Contaminated Soil. Archive of Environmental Contamination and Toxicol., 32: 166-171.
11. Gong, P., B.M. Wilke and S. Fleischmann, 1999. Soil Based Phytotoxicity of 2, 4, 6- trinitrotoluene (TNT) to Terrestrial Higher Plants. Archive of Environmental Contamination and Toxicol., 36: $152-157$.

12. Haimi, J., 2000. Decomposer animals and bioremediation of Soils. Environmental Pollution, 107: 233-238.

13. Marwood, T.M., K. Knoke, K. Yau, H. Lee, J.T. Trevors A. Suchorski-Tremblay C.A. Fleming, V. Hodge, D.L. Liu and A.G. Seech, 1998. Comparison of Toxicity Detected by Five Assays during Bioremediation of Diesel Fuel Spiked Soils. Environmental Toxicology and Water Quality, 13: 117-126.

14. Schlimme, W., M. Marchiani, K. Hanselmann and B. Jenni, 1999. BACTOX, a Rapid Bioassay That Uses Protozoa To Assess the Toxicity of Bacteria. Applied and Environmental Microbiol., 65(6): 2754-2757.

15. Kirk, J.L., J.N. Klironomos, H. Lee and J.T. Trevors, 2002. Phytotoxicity assay to assess plant species for phytoremediation of petroleum contaminated soil. Bioremediation J., 6: 57-63.

16. Omosun, G., H.O. Edeoga and A.A. Markson, 2009. Anatomical changes due to crude oil pollution and its heavy metals component in three Mucuna species, Recent Research in Sci. and Technol., 1(6): 264-269.

17. Sverdrup, G.D., C.M. Krogh P.H.T. Nielsen, C. Kjaer and J. Sternersen, 2003. Toxicity of eight polyclic aromatic compounds to red clover (Trifolium pretense), ryegrass (Lolium perenne) and mustard (Sinapsis alba). Chemosphere, 53: 993-1003.

18. Baud-Grasset, F., S. Baud-Grasset and S.I. Saffernan, 1993. Evaluation of the bioremediation of a contaminated soil with phytotoxicity tests. Chemosphere, 26: 1365-1374.

19. Banks, M.K., P. Kulakow, A.P. Schwab, Z. Chen and K. Rathbone, 2003. Degradation of crude oil in the rhizosphere of Sorghum bicolor. International J. Phytoremediation, 5(3): 225-234.

20. Huber, H.C., W. Huber and U. Ritter, 1990. Simple bioassays for evaluating toxicity of environmental chemicals using microcultures of human peripheral lymphocytes and monoxenic cultures of the ciliate Tetrahymena pyriformis. Zentbl. Hyg. Umweltmed. 189: 511-526. 
21. Baird, D.J., I. Barber, A.M.V.M. Soares and P. Calow, 1991. An early life-stage test with Daphnia magna Straus: an alternative to the 21-day chronic test? Ecotoxicology Environmental Safefy, 22: 1-7.

22. Lahti, K., J. Ahtiainen, J. Rapala, K. Sivonen and S.I. Niemela, 1995. Assessment of rapid bioassays for detecting cyanobacterial toxicity. Letter of Appl. Microbiol., 21: 109-114.

23. Sauvant, M.P., D. Pepin, J. Bohatier, C.A. Groliere and J. Guillot, 1997. Toxicity assessment of 16 inorganic environmental pollutants by six bioassays. Ecotoxicology and Environmental Safety, 37: 131-140.

24. Sayles, G.D., C.M. Acheson, M.J. Kupferle, Y. Shan, Q. Zhou, J.R. Meier, L. Chang and R.C. Brenner, 1999. Land treatment of PAH-contaminated soil: performance measured by chemical and toxicity assays. Environment Sci. and Technol., 33: 4310-4317.
25. Odiegah, P.G.C., O. Nurudeen and O.O. Amund, 1997. Genotoxicity of oilfield wastewater in Nigeria. Hereditas, 126: 161-167.

26. Inceer, H., S. Ayaz, O. Beyazoglu and E. Senturk, 2003 Cytogenetic effects of copper chloride on the root tip cells of Helianthus annus L. Turkish J. Biol., 27: 43-46.

27. Baek, K., H. Kim, H. Oh, B. Yoon, J. Kim and I. Lee, 2004. Effects of Crude Oil, Oil Components and Bioremediation on Plant Growth. A., 39(9): 2465-2472.

28. O'Brien, W.J., 1978. Toxicity of Prudhoe Bay Crude Oil to Alaskan Arctic Zooplankton, Arctic, 31(3): 214-228.

29. Sims, R.C. and M.R. Overcash, 1983. Fate of polynuclear aromatic compounds in soil-plant system. Residue Reviews, 88: 1-64. 